Social Research

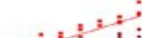

\title{
Oriental Traditions [Taoism]: A Critical Option for Peace Building Initiative in the Contemporary Society
}

\section{Dr Kingsley Okoro N.}

Department of Philosophy and Religion, Ebonyi State University, Abakaliki, Abakaliki-Nigeria

\section{ABSTRACT}

The $21^{\text {st }}$ century seems to have been eclipsed by conflict, which makes people presume conflict as necessary part of the society resulting to emphasize on peace education. This paper having taken a critical study on various peace building models of peace education observes that these models as good us they may be have not addressed the root of conflicts in the modern society. However, the researcher being interested in finding a peace building model that will address this gap spotlights on Taoism as having the potential to offering the world their peace-dream. This tradition anchors on the principles of Tao, Yin-yang and Wu-wei. Basic to the trio concepts are the idea of pluralism, non-interference, and non-action. This paper in adopting historical and sociological methods of investigations concludes that if Taoist tradition is adopted as a peace building model, the desired peace shall soon become a reality.

Keywords: Critical Option, Oriental Traditions. Peace Initiative, Taoism
*Correspondence to Author:

Dr Kingsley Okoro N.

Department of Philosophy and Religion, Ebonyi State University, Abakaliki, Abakaliki-Nigeria

How to cite this article:

Kingsley Okoro N. Oriental Traditions [Taoism]: A Critical Option for Peace Building Initiative in the Contemporary Society. International Journal of Social Research, 2017; 1:4.

\section{eSciencePublisher}

eSciPub LLC, Houston, TX USA. Website: http://escipub.com/ 


\section{Introduction}

Is a peace and peaceable society still attainable in our modern world? Is a peaceable society an illusion? Is peace an elusive concept or a human reality? The contemporary human experiences of bloody wars and crises in most part of the globe [East, West, North and South] warrant these barrage of questions and also crave for a sincere riposte to them. What would have made man to be hostile to himself, other humans and the environment? If the former questions must receive a genuine consideration, then the later question must be handled poignantly. In our attempt to providing an honest answer to the later question, we came to the understanding that values influence human principles and behaviours. We also discovered that the $21^{\text {st }}$ century is organized around the values and principles of western traditions, noting particularly that the entire world look up to Europe and the Americas for direction and guidance in almost all areas of her individual and corporate existences. The west has enforced her values on all the world through impositions, treaty, colonialization, subtlety etc. Therefore, the west set the standard in politics, economics, social life, security, welfare and warfare for the rest to follow. This they do to the exclusion of other world genuine traditions of the east and the aboriginal Australia and Africa.

Therefore, the recent edgy on wars, terrorist attacks, genocide, homicide etc. have cast doubts in the minds of many world citizens on the genuineness of the western epistemic traditions to guaranteeing a peaceable society of our dreams in the $21^{\text {st }}$ century. It could be noted that the western epistemic system which defines the values and nature of human relationship is bedevilled with many social flaws. It was Machiavelli who underscores part of the epistemic flaws as he notes thus, "European politics rested mainly on force and selfishness either of national or individual [Sabine and Thomas 1973: 422]. To this Hobbes adds that the desire for security in the face of such brutal force and avid individualism is therefore the real fundamental need of human nature [Leviathan 11]. Sabine and Thomas [1973] opine that this in all practical purposes is inseparable from the desire for power [429]. Hobbes explicates more on the value of power as he writes:
I put for a general inclination of mankind, a perpetual and restless desire of power after power that ceaseth only in death. And the cause of this is not always that man hopes for a more intensive delight than he has already attained or that he cannot be content with more moderate power but because he cannot assure the power and means to live well, which he hath at present without the acquisition of more [Leviathan 11].

Therefore, Hobbes subsumes that at the heart of the social crisis is the endless need for power of every sort and according to Sabine and Thomas [1973] this forfends the inevitable destruction which must end in the overtake of all men [429]. Therefore, each man is actuated only by the consideration that touch his own security or power and other human beings are only of consequence to him only as they affect this personal consideration. In his synopsis of the western social system, Hobbes maintains that human life in the state of nature is, 'solitary, nasty and short. It is state of war of all against all' [Bellum contra omnes] [Leviathan 11]. Here human beings have no real worth, personality and integrity and as such not protected against any onslaught [see Okoro and Osunwokeh 2014:3045-3067]. The overall effect of this epistemic system on global citizens is that human beings became shredded into social, religious and ethnic categories, as strong and weak, powerful and powerless, superior and inferior, men and women, developed and undeveloped, upper and lower castes [Okoro and Osunwokeh 2014: 79-93]. Accordingly, human history opened with competitive nature of human relationship and the outgrowth therefore becomes conflict within the social system [Okoro 2013: 12-23]. On the strength of the above postulation, Okoro [2012] summated that it was this ideology that brought about the slavery of certain portion of humanity within the $17^{\text {th }}$ and $19^{\text {th }}$ centuries. In justification of the claim, he cited a no less authority than Rhodes Ford, who maintained that modern slavery had proved that the Black people are distinctly inferior to the White People, while Philip Ulrich claimed that slavery in the antebellum America is a system of social control of the inferior being of the world [Okoro 2012:251-259]. In the same vein, William Dunning avers 'that the ultimate root of the trouble in the south has not been the institution of slavery but the coexistence in one society of two 
races so distinct in characteristic as to render coalescence' [Shade and Roy 1969:3-5], Against this backdrop, slaves were considered in antebellum south as property of the owner. The implication is that they were in absolute bondage as they have no civil right whatsoever and could not own property except at the will and pleasure of their masters [see Ulrich 1999:32 and Okoro 2012:251-259].

The epistemic system of dominance and subjugation of fellow human beings is noted here to be the foundation of modern western society. This according to Karl Marx resulted to alienation. Marx concludes that alienation brought with it the idea that human essence has no true reality at least in a class and alienated society [see Uchegbu 1997:280-312). Therefore, the struggle for quality, liberation and freedom of the oppressed in the alienated modern society become a commonplace activity and a critique and challenge to the sincerity of the world leaders in fostering peaceful social system and environment.

Faced with the criticisms and challenges, the western epistemic constructors instead of attempting the overhaul of their entire socio-political and economic system of dominance to giving it a clear human and moral face introduced what may be describe as a palliative model in the form of peace building and conflict management, however this model seems artificial as it never dealt with the root of the conflict in the human society. Hence [Okoro 2013] observes the fatal failure of this palliative model in spite of the huge resources in time, money and energy invested in the promotion of the model, since conflict in large and small scales are still our daily experiences. Accordingly, Okoro [2013] expressed his doubts in the invincibility of the modern peace building model to producing positive effect in our socio-political milieu in the following idea:

...several attempts have been made to inculcate peace attitudes through intensive teaching, training and workshop. These programmes gave birth to peace and conflict management studies that have come in vogue in the recent academic researches... what constitute the core of peace education curriculum has been a thorny issue among scholars of peace studies. The controversy has resulted to mottled curric- ular. Being divided in discipline, orientation, methodology and interest, scholars of peace studies, have proposed biological, sociological, philosophical, political, anthropological, and traditional approaches to building curriculum for peace education. These approaches as good as they may be have failed to provide solution to the peace challenges/needs of the contemporary society [87-112].

Against this backdrop of the observable and fatalistic failure of the western value system in fostering peace and peaceable society, we therefore turn our search to the oriental world. Here we spotlight on the moral principle that underlies the principle and practice of Taoism [Daoism]. The basic principle of this Chinese traditional thought and faith [Taoism] hinges on the principle of 'Tao, Yin and Yang' and 'Wu-wei'. This paper thus undertook the study of this ancient Chinese moral values with the aim of finding its viability in fostering the desired peace in the modern society and concludes that if modern society shall adopt this moral principle, she shall be awe-stricken as she finds that conflict is not synonymous with humanity as we have been wheedled to accept and propagate.

Taoism [Daoism]: A Brief Historical Perspective

It is said that Taoism is the only true home grown Chinese religion. Buddhism was imported from India and Confucianism is mainly a philosophy [see mystic politic. www.taoismimmodernhistory/edu.org.]. Actually, the founding and the basic teaching of Taoism are attributed to the legendary figure, Lao Tzu. The name means, "Old master or Old boy" Lao Tzu is believed to have been born around 604 BC [see Wolff 2007: 118]. However, almost nothing is known about his life. This is because he made serious efforts to live an unnoticed life, he lived in obscurity as he remained silent, unknown and unnamed. According to Edet [2006] Lao Tzu's real name is Li Uhr and he was born in a farm in the province of Honan [126]. The mythical obscurity in which Lao Tzu covered himself with warranted many within the oriental scholarly circle to consider him as a legendary figure. This assumption is justified by this story told by Edet [2006] thus:

With regard to the finest figure of Chinese heritage, Lao Tzu, legend has it that his 
mother carried his pregnancy for a very long time that when he was born, his hair had already turned white and he was seventy-two years old. Because of this surprising fact, he was nicknamed Lao Tzu, which means Old boy or Old master [126].

He was born in a period in Chinese history, when the society was facing great social crisis and many thinkers and great philosophers were poised to searching for a model solution in order to salvage the society from disintegration and fatal collapse. Personalities like Confucius played prominent role in this quest for solution within this period. However, in the face of such turbulent situation and social challenges, Lao Tzu choose to remain quiet and unnoticed. According to Taoist scholars, Lao Tzu worked in the imperial archives at Loyang in central China, where he became renowned for his wisdom. While working in Loyang, he met Confucius, whom he disparaged and also derided his teachings as a demonstration of selfishness and imposition of self will upon the society. Lao Tzu attempted convincing Confucius of the futility and hopelessness of his efforts to improve the society by direct efforts, on the other hand, Confucius admired him for his quiet dispositions and the principle of inaction, [see Edet 2006: 127]. The legend surrounding Lao Tzu's personality is reflected in Taoist sources thus:

Lao Tzu however became dissatisfied with the turbulent and chaotic situation of China of his time and as he could not understand the reason for the craze for wealth, fame and power and the corruption of the rulers, then one day he decided to shun the society and return to nature. Here Lao Tzu is said to have climbed on water buffalo and ridden to the west towards Tibet, in search of solitude for his last few years. On his way, he was asked by the gate keeper to leave behind him a record of his belief [see mystic politics@www.taoismin modernhistory/edu.org.]

There upon, Lao Tzu stopped and wrote his famous book, "Tao Te Ching" in five thousand Chinese characters and then continued his journey and when he had gone far on the mountain, he disappeared into a cloud and was never seen again [see Edet 2006:127].
In his description of the "Tao Te Ching" the famous sacred book of Taoism, Wolff [2007] notes, "Tao Te Ching', of which Lao Tzu is the putative author... is among the most obscure books in the world. It is probably a compilation of fragments from the Sixth to the fourth centuries [119]. It was the Tao Te Ching that defined the basic teachings of Taoism. Here the central theme is the Tao [the way] and Te [power]. Some scholars are of the opinion that though there might be other sources earlier than Tao Te Ching but the general belief among all the shades of the schools of thought in Taoism is that the Tao Te Ching is the foremost scripture of the entire Taoist tradition. Nevertheless, the consensus among Taoist scholars is that Tao Te Ching in its present form is not the work of one single author and Lao Tzu is simply the appellation of the symbolic Taoist sage, whose doctrine are reflected therein in the Tao Te Ching [See Pregadio 2005 1-16].

Besides the Tao Te Ching [The book of the Way and its power] Taoists regard Zhuangzi [the book of master Zhuang] as being complementary to Tao Te Ching. This provides Taoism with the doctrines, notions, and technical vocabulary throughout history. Zhuangzi is therefore considered to be one of the finest literary production of Chinese tradition. Zhuangzi is slightly different from Tao Te Ching from the point of view of its formal features as it consists mainly of stories, anecdotes and reflections. However, in spite of the seeming differences between Tao Te Ching and Zhuangzi, the two sacred text of Taoism present the same view of the Tao and its relation to the world. In the idea Edet [2006]

Zhuang, who is without question, the most important Taoist next to Lao Tzu. In his book Zhuangzi, he not only elaborated on the Tao but also expounded on the ideas of yin and yang. As expected Zhuang thoughts did not deviate from that of Lao Tzu [141].

The main emphasis of the two sacred book is the Tao [Dao] The word Tao in the idea of Pregadio [2005] has the two meaning, 'Way' and 'Method' These two words, accordingly refers to the way in which something is or the way it functions and the way of doing something [including] the extended meaning of practice in religious senses] [1-16]. While, Edet [2006] underscores that the word Tao would be variously translated as the 
way', 'the road' 'the path' or 'the origin' of everything [128]. In the same vein. Hays (2013) describes it as the way which points mainly to the divine way of the universe and the 'unproduced producer of all things' [1-8]. On the other hand, 'Te' is the power/virtue that is the power of the Tao and the power to bring Tao into realization.

Notably, it is impossible to clearly define the 'Tao' and it's Te' in human language or category. This is because the Tao that can be clearly named is no Tao at all, therefore, the numerous definitions and descriptions. The basic idea about the Tao as enunciated by Lao Tzu is that Tao is not a god but rather a force or principle that over flows all things. Accordingly, Robinet [1997] defines it as the 'Absolute' and still maintains that the Tao has no name and as such beyond description [26]. The word Tao is only being used because one is forced to refer to it. Notably, majority of Taoist scholars accept that Tao is unknowable, has no form and as such does not undergo changes. It is constant, invisible, inaudible, and imperceptible [Robinet 1997:41] The Tao cannot be perceived because according to Taoists, it exceeds the sense, thought and imaginations but can only be known through mystical insights, which cannot be expressed in words. In affirmation of the foregoing notion of the Tao, Omeregbe [1991] asserts:

Tao is superior to all things, before all things and ultimate source of all things. It pervades all things and is therefore in all things. Tao has no name, no form, yet it flows everywhere, manifests itself in all things and pervades the whole reality. It is boundless, self-existing, self-actuating and self-defensive. It is the underlying unity of multiplicity, the harmony of opposites, the undifferentiated one, the real one, the Great one, in fact, Tao is not simply the great but is Greatness itself. It is the sum total of which all things are part, silent, empty, existing by itself, unchanging and inexhaustible [290].

In the Tao Te Ching itself, Tao is described thus:

It may be called the mother of the world, its name is unknown. I simply call it Great means extending to the limitless. Extending to the limitless means reaching the extreme distance. Reaching the extreme distance means returning to the nearness.
Thus Tao is great. The Tao that can be spoken of is not the Tao itself. The Unnamed is the source of the universe and the originator of all things. Therefore, often times, without intention. I see the wonder of Tao. I see its manifestation [Chang Chung Yuam 1978:73\}.

On the concept of Te [power/virtue] which is always closely associated with Tao, scholars of oriental philosophy maintain that the $\mathrm{Te}[\mathrm{De}]$ is power/virtue and with Tao [Dao] formed the core of Taoist canons. Tao is the internal law of all things, while Te is the power of Tao and the concrete expressions of Tao in all things [Mystic politics 2015: 1-9]. Accordingly, Tao originates all things and Te fosters them. Therefore, all beings revere the Tao and honour the Te. In actuality, there is a water tight relationship that defines the modes of operation between the Tao and the Te. Here Te means merit, actions and demonstrations of the Tao [mystic politics 2015:1-9]. In the same vein. Barrett [1996] describes the Te as the mystery within mystery [22]. The Tao Te Ching, outlines the process which happens with no cause or purpose. It maintains that the Tao generates the one, the one generates the two, and the two generates the three and the three generates the ten thousand.

This simply means that the Tao first generates the one [Yi] which is the principle of unity of existence in which individual entities defined by forms and names are included but have not emerged. The one differentiates into the two polar and complementary principle of yin and yang. The three is the product of the meeting of yin and yang and it represents the one re-established at the level of each individual entity. The ten thousand things [wanwu] are the yin and yang. This connotes both a metaphysical and cosmogonical formularies. It represents the metaphysical nature of the Tao and the Te by the arrangement of the single item in a hierarchical order designed to show the ultimate origin of the Tao. In cosmogony, it is the motion which shows continues reiteration of itself within each of the cosmic cycle that Tao brings into existence [see Pregadio 2005:1-16].

Accordingly, with the force of the Te, both the Tao and the Te manifested world model themselves in ziran. Ziran literary means 'to be so of 
its own'. Thus with reference to the Tao, ziran means that there is no ultimate reason for things being as they are: the Tao generates the ten thousand things but while for the relative, the absolute is the mother, for the absolute, the relative does not exist. Aside from generating the world, therefore, the Tao does nothing else. It does not act in it. It is not affected by the transformation, decay and disappearance of the forms it generates [Pregadio 2005:1-16] and it is neither rejoices in nor is hurt by what is in relative sense of good or bad.

Then from human synopsis, Tao refers to man's virtue and good deeds. The general aphorism, 'Tao in me is the Te' underscores this basic assumptions. Here Te is the manifestation of Tao. A person may feel at ease if he does good deeds and accumulates virtue. When he feels at ease he has attained Tao. The principle doctrine of Taoism that binds the Tao, the Te and the universe and human beings in an inseparable manner therefore becomes the doctrine of yin and yang and Wu-wei. We shall dedicate the next section of this work to explicating on this basic doctrine, taking special consideration of their basic imagery, nature and development.

\section{Principles/Canons of Taoism in Perspective.}

The basic canons of Taoism could be summed up in one word "None-Interference". This is done through following the Tao, which is often taken to be synonymous with nature. According to Lao Tzu, the legendary father of Taoism, what mankind needs to live happily in the world is noninterference with nature but to humbly understand the way it works and this knowledge is attained through understanding the Tao itself. [See Edet 2006 132]. Therefore, Taoists proposed that mankind simply needs to live in harmony with the Tao and to achieve this state, one needs to seek understanding of the qualities of the Tao. Here the Tao takes no action and yet leaves nothing undone. The Tao does not compete and yet skillfully achieves victory, the Tao never desires to reach the extreme and yet it covers all grounds. Consequently, non-action, non-competiveness, non-domination and the maintenance of equipoise are the great qualities of the Tao.

The great sage maintains that non-action is stronger than action, hence gentleness overcomes strength, kindness conquers hardness and to yield is to conquer. Paradoxically the nature of the Tao is stated thus by the sage, 'to be inactive is to act, to be empty is to be full, to have plenty is to be confused, to know too many things is to be unwise, to have little is to be rich, to be active is to do nothing, to be silent is to teach, to be meek is to be strong' [Tao Te Ching chapter 3]. This is the way of the Tao and if mankind shall learn to follow it, everything would be harmonious, peaceful and effective in the humanity's world. This fundamental doctrine is set forth in the two major concepts that properly define Taoism. These are the concepts of Yin-Yang and Wu-Wei. We shall therefore spare some time to do brief discussions on these concepts.

a. Yin-Yang. Overtly, Yin-yang is one of the dominant theories shared by different philosophical schools of Taoism [Wang 2015: 1-5 see also http:/www.internetencyclopdiaofphilosophy.org/ edu]. The idea of yin and yang according to Wang has greatly influenced the Chinese culture. The concept is obviously hard to be defined with a simple category. However, there are three basic elements that throw a shadow to the understanding of this mystique concept -yin and yang. These are;

i. Yin-yang is considered as the coherent fabric of nature and mind that exhibits itself in all existence.

ii. Yin-yang is also looked upon as the basis of interactions in the natural world. This interaction defines the relationship between the waxing and waning of the cosmic and human realms

iii. It is also seen as the process of harmonization, which ensures a constant and dynamic balance of all things.

Accordingly, Zhuangzi describes it in its different categories and underscores the fact that yin is the highest freezing point, while yang is highest form in boiling. The chillness comes from heaven [yin] the warmness comes from the earth [yang]. Hence the interaction of the two to establish harmony as it gives birth to all things [see Zhuangzi chapter 2]

With regard to the origin of this concept, Wang [2015] reiterates that the earliest Chinese characters which form the ideology of yin and yang 
are found in the inscription made on the oracular bones. In these inscriptions, yin and yang were simply described as a natural phenomenon as weather conditions attached especially to the movement of the solar system. Thus, the sunlight during the day refers to yang, while the lack of it during the night is referred to as the yin. Here yin is thought of as 'closed door' in many Chinese literatures. Yin is also thought of as darkness and the south side of a river and north side of a mountain [see Wang 2015:I-6]. On the other hand, yang refers to height, brightness, and the south side of a mountain. This means that the concept of yin-yang is derivative. It is derived from the daily life routine of the ancient people, whose livelihood and subsistence depend solely on the sun for lightening and daily routine. Thus when the sun rises, they will be out in the field and when it sets they would return home and take their rest. It is against the backdrop of the movement of the solar system that the conceptual frame work of yin and yang is developed and sustained. Hence yang [dong] active and yin [jing] is rest.

Within its period of early development, yin and yang existed independently and were not connected to each other [see Wang 2015:1-6]. However, in the course of historical development, the two characters of yin and yang began to assume complementarily. This complementarily status was not attended accidentally but by the means of synchronicity. This connotes that yin follows yang simultaneously without causing yang. Thus the relationship represents different sides of the same idea. As such, yang is the sunny side and yin the shady side of all the phenomena in the universe.

Notably, the concept of yin and yang has undergone several changes and modifications and this is as a result of philosophical and historical development that occurred in the ancient China. In spite of these notable changes, the nucleus of the idea has not changed. Thus within all the different schools of Taoism, there is a general consensus that central to the concept of yin and yang is the concept of qi also known as ch'i and means vital energy. Thus yin and yang are considered as the vital energy that freely operate and organize the universe in its order [see Legge 1994:580]. Accordingly, the qi manifests itself through the six heavenly influences which de- scend on the earth and produce the five tastes, produce the five colours and verified in the five notes of music. However, whenever the qi is in excess, it produces the six diseases. These six influences are domesticated in the concept of yin, yang, wind, rain, obscurity, and brightness. According to Legge [1994), it is through the separation of these six elements that the four seasons are formed, while in their unity they form the five terms but when any of them is in excess calamity ensures. Hence an excess of yin leads to the disease of cold and when yang is in excess, it produces the disease of heat. [580]

Overtly, yin and yang are the vital energy of the universe and the qi flows within the natural as well as the human worlds, hence they are the fundamental fabrics of all existences. Therefore, heaven and earth have their regular ways and human beings should follow the pattern, thus imitating the brilliant bodies of heaven and walk in tandem with the natural diversities of the earth. Therefore, heaven and earth produce the six atmosphere condition [qi] and make use of the five material elements [Wang 20151-6]. When therefore, they are in excess they produce obscurity and confusion and mankind loses their proper nature, which include but not limited to mildness, gentleness, kindness and harmony.

The qi [vital energy] also produce the one and its opposite as love and hatred, pleasure and anger, grief and joy etc. Accordingly, the Taoists maintain that a careful imitation of the working of the qi to regenerate the six impulses through ritual ceremonies. This is because when there is failure in joy and grief, we have a state of harmony with which the nature of heaven and earth can endure [See Legge 1994: 708]. Qi is therefore a force, which arise from the interplay between yin and yang and it also provides a conundrum upon which yin-yang is seated and functions. Through the qi, yin and yang provides explanation for the mystery of the universe and serves as the foundation of the Chinese intellectual heritage. Hence Lao Tzu in Tao Te ching avers that everything is embedded in yin and embraced in the yang and through the agency of the qi, it reaches harmony. Thus, yin-yang when it functions as the qi provides interaction between everything that comes into existence [see Tao Te Ching chapter 42 www.understandingtaoisin.org/edu]. Zhuangzi speaks of the qi of yin and yang as 
the balancing of the equilibrium in the material universe. Accordingly, when qi of yin and yang are not in harmony and cold and heat come in untimely way, all things get hurt [Zhuangzi chapter 2]. However, when both have intercourse and attain harmony through the vital energy [qi] all things are produced.

Here we understand yin and yang as they operation of the qi in the dynamic and natural form of flowing energy, a complimentary primordial potency of the universe. Against this backdrop, Henderson [1984] explains further:

When heaven and earth were formed, they divided into yin and yang. Yang is generated from yin and yin is generated form yang. Yin and yang mutually alternate which makes four field -celestial circle. Sometimes there is life, sometimes there is death that brings the myriad things to completion [72]

Accordingly, TCM [2015] explicates further on the complementarity ideality of yin and yang, when they opine that:

Everything contains yin and yang. They are two opposites yet complementary energies. What does this really mean? Although they are totally different -opposite- in their individual qualities and nature, they are interdependent. Yin and yang cannot exist without each other. They are never separate, for example, night and day form the yin and yang pair [night is yin, while yang is day]. Night looks as if it is very different from the day, yet it is impossible to have one without the other. Both create a totality, a complete whole [1-7 see-also http://wvvw.tcmvvorld. org.whatistcm/yinyang.edu]

This inseparable and interpenetrating relationship that govern the universe as a holistic system is carefully represented in the yin and yang symbol below

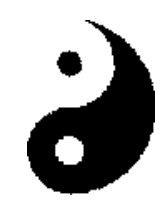

[This symbol is extracted from Wikipedia, the free encyclopedia]

Note that in the symbol above that the small dot within each of the two energies -represented by black and white 'symbolizes that there is always some yin [black] in the yang [white] and vice versa. Therefore, nothing in this life is absolute as shown in the yin and yang symbol. This ideality supplies a unitary vision of life -heaven, earth and human beings -and makes intelligible in terms of resonance between beings and the universe. In summation, the oriental tradition [Chinese] yin-yang model-yin [black] contains within it a seed of yang in the form of white dot. There is therefore yin but the interesting thing is that within yang there is also the seed of yin in the form of black dot. The implication is that yin has the ability to transform itself into yang and vice versa. This transformation is possible because each energy though different from the other contains the seed of each other. Thus there is a balance in their operation, however, their relationship goes beyond the state of balance to one of harmony. When two things are balanced, they are simply equal but still separate but in a relationship of harmony, the two energies blend into a seamless whole as perfectly embodied by the swirling yin -yang symbol above.

b. Wu-wei. The second important concept that defines major doctrine of Taoism is the concept of Wu-wei. Here Tao Te Ching defines it in vivid terns thus:

Weakness is the function of the Tao...Nothing in the world is softer and weaker than water, but no force can compare with it in attacking the hard and strong... the soft can overcome the hard and the weak can overcome strong ....when alive, man is soft and tender, after death, he is hard and stiff. All things like grass and trees are soft and tender when alive, whereas they become withered and dried when dead. ..the hard and stiff are companions of death, whereas the soft and the tender are companions of life. Being weak and soft does not mean being cowardly but being resilient [chapter 43 see also mysticpoliticsllwww.understandingtaoism.org//edu].

Wu-wei is symbolically represented with the imagery of water and its underlying message is that life is a constituent of organic, interconnected whole which undergoes constant transformation. It is this central message of Taoism that is 
represented in the concept of wu-wei that made Kurdash [1993] to write that the unceasing flow of change manifests itself as the natural order governed by unalterable yet perceptible laws. Paradoxically, it is the constancy of these governing principle that allows people to recognize and utilize them in their own process of transformation. Gaining awareness of life essential unity and learning to cooperate with the natural flow and order enables people to attain a state of being that is both full, free and independent and at the same time fully connect to the life flow of the universe [1-6].

This ideology has become the benchmark in realizing oneness with the Tao as set forth in Taoists canons. This oneness ideology is embedded in the concept of Wu-wei, which simply translates as "non-doing'. Wu-wei technically refers to a behaviour that arise from a sense of oneself as connected to other selves' bound to the environment. It is not ruled by a relationship of separateness rather it based its actions on effortlessness and spontaneity. In his own attempt to defining the concept-Wu-wei, Burrough [2008] writes.

\section{Wu-wei [Chinese, literally non-doing] means natural actions or in order words, action that does not involve struggle or ex- cessive efforts. Wu-wei is the cultivation of the mental state in which our actions are quite effortless in alignment with the flow of life. This is going with the flow, although, it may be greatly productive, is still character- ized by great ease where we spontaneous- ly act perfectly [1-6].}

In his own opinion, Watts [2008] maintains that:

Wu-wei means natural action-as the planets revolves around the sun, they do the revolving but without doing it, wu may be translated as not to have or without, wei may, on the other hand, may be translated as do action, it serves as, govern or effort. The literal meaning of wu-wei is without action and it is often included in the paradox, 'wei-wu-wei which translates, action without action or effortless doing [1-6].

Wu wei, being the correct attitude of a true Taoist, denotes creative quietude. It is adopted as a way of living, which avoids wasting of life force or vital energy [qi] through friction and conflict.
Accordingly, Wolff [2004] opines that to cultivate wu-wei is to further inhabit the peripheries of emptiness and abide in the tranquil centre [120]

Notably, in the original Taoist texts, [Tao Te Ching and Zhuangzi] wu-wei is associated with water and its yielding as already noted earlier in this paper. Thus, though water is soft and weak, it has the potentials of overriding and washing away even the solid stone and also move the highest mountains. Water is without will though it may be understood to be opposing and possessing all things, including wood, stone and all the aggregated solid materials. Due to its nature and propensity, water may potentially fill any container, assumes any shape and when given a cycle, water may potentially go anywhere even into the minutest holes both metaphorical and actual. Droplets of water, when falling as rain, gather in watersheds, flowing into and forms rivers of water, enjoining the proverbial sea. Furthermore, whilst always yielding downwards, water finds its own level in the dark valleys -where biological life is regenerated -analogous to the fecund reproductive organs [see Watts 2008:1-6]

Wu-wei is thus a major principle in the realization of oneness with the Tao. Meaning non doing or none action, wu-wei refers to the behaviours that arise from the sense of oneness with nature and the interdependence with other selves. Thus one considers oneself as connected to other selves and to one's environment [Kurdish 1993: 1-6]. Here the essence of life and living is not motivated by sense of separateness from the universal system rather one's action is guided by spontaneity and effortlessness and at the same time it is not motivated by inertia, laziness or mere passivity. Wu-wei living is the experience of going with the flow, the grain or swimming with the current [Kardsah 1993:1 -6]. In active term therefore, wu-wei living means 'going with the flow'. This behaviour simply occurs in response to the flow of the Tao. Thus, wu-wei suffices the right action in any given situation. This is the action that flows naturally because we are connected to the flow of life.

This fundamental understanding of Wu-wei gives vent to the fact that nature/universe already works harmoniously according to its own will, thus if a person exerts his/her own will against or upon it, the person disrupts the harmony that already 
exists and the consequence is always untold. However, this is not to say that a person should not exert agency and will rather it is how one acts in relation to the natural process already extant. The poem that follows accredited to the sage, Lao Tzu defines the flow of the Tao explicitly. The sage is occupied with the unspoken. And acts without efforts, teaching without verbosity. Producing without processing Creating without regard to result. Claiming nothing, the sage has nothing to lose [Tao Te Ching 28].

In summary therefore, as one diminishes doing- doing here means those intentional actions taken to benefit one or actions taken to change the world from its natural state and evolution-one diminishes those actions committed against the Tao, the present natural harmony. As one cultivates the Tao, he becomes more and more in harmony with the Tao and through this he attains the state of "Ming" [Zhuangzi chapter 3] Ming simply means "clear seeing" or "choiceless awareness" it is in this state of Ming that Taoists is in full harmony with the Tao and having achieved this point of non-action, there is nothing that is left undone. It is upon the achievement of this enlightened status that the sage begins to perform wei-wu-wei [action without action]. Here the state of oneness with nature is attained and one discovers the secret of harmonious living with nature and the repulsiveness of detached living in the natural environment.

Hermeneutical Discourse on Oriental Traditions [Taoism] As Critical Option for Modern Peace Building

...govern the state with correctness...administer the empire by engaging in no activity...He who assist the ruler with the Tao does not dominate the world with force. The use of force usually brings requital. Where armies are stationed, briers and thorns grow ...whatever is contrary to will soon perish [Brooker and Kenneth 1998:569]

This Taoist political philosophy was set against the background of Confucianism [another ancient Chinese Religion], which taught that the social order will be maintained when everybody within the state acts his part according to stipulated pattern. Confucius, the founder of this socio- religious-philosophy, codified human relationship pattern as model for human social behaviour. In this order, Lao Tzu saw social defects on such stratified order of relationship and opines that what is needed to order the society and achieve a peaceful social system is but 'Non-interference' with the order found in the world but to humbly understand and follow the Tao [Nature] as it acts by its own order [see Edet 2006:132]. Lao Tzu, in maintaining the position of non-interference with nature proposed that human being cannot force change on the world without disastrous effects. Therefore, the only duty of man in the world is simply to seek harmony with the Tao [nature].

Lao Tzu maintains that it in seeking and maintaining harmony with the Tao that a true peace and stability will be attained in the world. He further underscores the fact that the more men interfere with the natural balance produced and governed by the universal law, the further away the harmony retreat into distance [see Taoism as lived by pooh and Piglet. hpp//www.taoisminthemodernworld.org/edu]. According to Lao Tzu, the world is not a setter of trap but a teacher of value lessons and its lessons are needed to be learnt and it laws followed and in return a peaceful social order will be achieved. Against this backdrop, Lao Tzu maintains that the origin of the present world crisis, confusion, conflict and war is man's interference with the order of nature. He explicated on this assumption in a fanciful and mythical story thus:

Thousands of years ago, man lived in harmony with the rest of the natural world. Through what we would today call telepathy, he communicated with animals, plants and other life forms, none of which he considered 'beneath' himself only different from them with different jobs to perform. He worked side by side with earth angels and nature spirits, with whom he shared responsibility for taking care of the world [Taoism as Lived by Pooh and Piglet]

In this state of nature, Lao Tzu continues, the earth was more supportive and this resulted to tremendous variety of vegetables, fruits, seeds, and grains for food and everything played its role to support the harmonious living and productivity within the earth system. Here man lived at peace with himself and various forms of life, whom he considers his teacher and friend. However, this state of harmony was gradually and eventually 
broken when man began to be "egocentric" and assert himself on the social system as its lord and master, with overriding power to dominate other form' of life. This haughty disposition of man wrecked innumerable unpleasant incidents, then the other forms of life, who were human partners reached a consensus to throw man out into the harsh realities of the world with the aim that man might learn his lessons and better understand himself and his position as a caregiver to the world and also as an integral part of the created order and of Tao itself. With this action, the connection between man and the nature was permanently broken.

The consequence of this uncanny incident was that man was gripped with great sense of alienation from the world he had been created from and was part of. Being cut off from the abundant natural resources he had enjoyed, man lost happiness and began a lonely life. Desperate in the quest to achieve peace and happiness again, he began a journey into the unknown and mysterious world and without knowing what he really lost and needed. Therefore, whenever he finds something that reminds him of the happy estate he had lost, he seizes it with ferocity and loses no opportunity in accumulating more of it. By this action man introduced stress into the social system. However, searching for lasting happiness and accumulating temporary substitutes gave man no satisfaction, thus with the passage of time, man lost his track in his earth journey by losing the connection with other life forms. In the words of Lao Tzu,

Man was no longer able to hear what other forms of life were saying, he could only try to understand them through their action which he often misinterprets. Because he was no longer cooperating with earth angels and nature spirits for the good of all but was attempting to manipulate the earth forces for his own benefit alone. Then plants began to shrivel and die, with less vegetation to draw up and give off moisture, the planet' atmosphere became drier and desert appeared ....Eventually the earth lost the radiant colours and the abundant fruits of their ancestors... Because of the decreasing variety of food available to man -and his growing insensitivity-man began to kill and eat his friends, the animals [see Taoism as

\section{Lived by Pooh and Piglet]}

With this latest development, man's alienation grew in intensity and the consequence was that he became more and more manipulative of and violent towards the earth. The result therefore became narrowing down of his social and spiritual world. This yielded in man the power to becoming more manipulative and violent towards his own kind. Thus man began to kill each other. He began to create armies and empires and forcing those who looked, talked, thought and act differently from him to submit to what he thought was best. It is under this condition that the world reached its present state and if nothing radically in terms of remodeling the current epistemic system to reflect the nature's path to harmony, then we shall be heading heedlessly towards self-annihilation, thereby fulfilling an ancient Chinese [Hopi] prophesy of impending doom to the humanity occasioned by selfishness and avariciousness. This prophesy is retold by Hansen [2015] thus:

White people would bring the 'gourd of ashes' that would create great destruction and loss of human life upon the earth. They believed that gourd of ashes refers to the atomic and nuclear bombs. Then speaking to the United Nations, Hopi elder Thomas Bamyacya said, if you, the Nations of this earth create another great war, the Hopi believed we human, will burn ourselves to death with ashes 156]

Against the backdrop of the story of human alienation from himself, the other forms of life, the universe and the impending danger looming large over the human horizon that Taoism as a synthesis of religion and socio-political philosophy arches out a non-interference attitude to the established order of thing and a return to nature as its core of political philosophy.

On the one hand, Taoism rejects the Confucian/ modern emphasis on social hierarchies and divides, which it considers as the basis of the present unjust social order. On the other hand, Taoism places emphasis on the importance of good life pattern, which can only be attained by simply following the Tao. Hence Taoism as a socio-political philosophy condemns the imposition of a single Tao [way/ method and/or culture] on the people. Taoism's ethical theory is based on plu- 
ralism. In justification of the assumption, Toropov [2011] asserts, 'Taoism mainstay is its emphasis on variety, pluralism and allowing different perspectives to coexist [1-11]. Accordingly, Taoism could be regarded as both egalitarian and libertarian in its conception of freedom. However, Taoism does not promote the individualism of persons both the individualism of the state, thus it is pluralistic and envisions a peaceful world in which people, group and institution experiment with the ways of life and choose them in the openness and tolerance [ The Tao Bums 2015:1-14]. In vouching for pluralism of the states and the encouragement of various perspectives of ideas, Taoism sustains that no single guiding Tao [way, path, method, culture] can be right. It thus condemns the quest for uniformity in culture and morality. On this note Taoism promotes a passive approach in administration of the state rather than a paternal approach, maintaining that wars are usually fought for what each side thought was morally, socially, and ethical important and often for selfish reasons/interests.

In promoting passivity in administration, Lao Tzu recognized that it is coercion, the use of force in the administration of the people or maintaining of a single view point that brings about retaliation and hostility. Against this backdrop, Taoism deemphasises divisive initiatives and asserts that the leader should be able manage rivalries before they actually begin. He should also shun material wealth and other lurid trappings of power. On the contrary, he should cultivate simplicity by means of personal example as he should lead the population. [Marina 2001:1-14]. Lao Tzu notes that ambitious competition for social status, ostentatious living, strife, violence and wars are promoted in the social system by giving special attention and recognition to knowledge sophistication or the encouragement of a single scheme of knowledge or field of knowledge. He expressed this ideality in the following lines of Tao Te Ching Chapter 3 thus:

If you over esteem talented person, people will become competitive. If you over value possessions, people will begin to steal. Do not display your treasures or people will become envious. The master leads by emptying people's mind from coveting, filling their bellies, weaken their ambition and make them become strong. If the people are sim- ple and have no desire those without virtue dare not act against them because the master practices non doing and everything will fall in place [Tao Te Ching Chapter 3 McDonald translation]

The good leader in Taoists perspective is the one that knows that to draw people away from their natural roots [current globalization] invites ever more complicated political situation and this encourages rivalries and unending competition. This political strategy influenced the Chinese traditional understanding of governance. Here the prince sits at the right place and facing the south and with contemporary of Lao Tzu, compares a virtuous prince to the North Pole in which he finds himself, he does not move and everything turns around him. The implication of this governance model is that the best government is the one that makes its presence least visible and the best leader in Taoist perspective is the one who speaks infrequently. Taoism therefore encourages that people should be left alone to pursue their own conception of good, since authoritarianism is always known to have started with selfstyled genius, who claims to know what is good for everybody else.

Taoism notes that the world system after the mythological fall is structured around the ideology of advancement, expansion and activity and this reflects the male -yang side of the human nature. Lao Tzu condemns this position as the source of all conflicts in the social system. He then proposed that leaders should not only emphasis but wholly adopt the method of retreat, intuition, reduction and passivity-the way of the female-yin. This ideology of course has nothing to do with human gender division but with the outlook one takes on the job of leadership. Taoism, therefore, maintains that leaders rather than being over bearing and demanding father, should be supportive mother, if leaders of the state should adopt the metaphor of a supportive mother, then they should be able to nurture and support all ways of life that people spontaneously choose. The leaders should remain impartial on the ultimate question of the right path [Tao] to follow and tolerate all in the social system [Toropov 2011; 1 -14].

Lao Tzu maintains that the female approach is the most effective way of overcoming opposi- 
tion, political; or otherwise. He elucidates more on this female imagery of leadership thus, 'The female constants using stillness, she conquers the male, using stillness to act out 'beneath'. Hence if great states use 'beneath' on small states then they take small states' [Tao Te Ching Chapter 61]. By this proposition, Taoism advocates for the strategy of non-acquisitiveness in governance. The core of this stratagem is the avoidance of instruments of war. Accordingly, weapons are regarded as the instrument of evil rather than instrument of peace and good leadership (Brooker and Kenneth 1998:62]. Taoism notes that if world leadership apply the female gift of intuition ${ }^{\wedge}$ they can avoid conflicts by anticipation, proactivity and reconciling enemies and resolving difficulties before their escalation. By the use of intuition [the character of the yin] the wise leader scores a resounding success that beats the imagination of the natural men, who use the male [yang] approach in handling conflicts. The wise leader of Taoist perspective understands that there is no safety in the use of force in the organization of the state, he remains calm and unhurried in dealing with any problem that cannot be avoided. Thus he prefers yielding rather than attacking. By this he put the principle of Wu-wei [flowing with the tide] into practical relevance.

The basic implication of the principles enunciated above is that a good leader in his effort to maintaining a stable and peaceful state does not aim at dominating or exploiting others. $\mathrm{He}$ is rather open and broadminded. The very essence of Taoist political philosophy lies in not returning injury with injury, a practice which leads to endless cycle of revenge [see Edet 2006:138]. The wise leader rather chooses to remain faithful to unfaithfulness in this way he gradually and effortlessly turns the people away from the lower and beastly nature that tend to dominate rather than blend with human beings and other forms of life.

The bottom-line of Lao Tzu teaching on governance, peace and conflict management could be summarized in this long citation.

.. .The more prohibitions you make, the poorer the people will be. The more weapons you possess, the greater the chaos in your country. The more knowledge that is acquired, the stranger the world will be- come. The more laws that you make, the greater the number of criminals. Therefore, the master says: I do nothing and the people become good themselves. I seek peace and the people take care of their own problems. I do not meddle in their personal lives and the people become prosperous. I let go of all my desires and the people return to the uncarved block [Tao Te Ching chapter 57].

Against this backdrop, whenever there are socio-political conflicts, whenever the people become rebellious and whenever there is hardship and suffering among the populace of the society, Lao Tzu sees human greed, abuse of power, neglect of the Tao, heedlessness, pride and selfishness on the part of the leadership as the cause. Therefore, to solve such social problem Tao Tzu enunciates as follows:

Starvation among the people come from the amount of tax-in-kind. Those above the people eat from this and the people starve. The difficulty in governing the people arises when those above the people deem and enact from this the people are difficult to govern. The people take death lightly because those above them seek life's riches. In general, only those who don't deem and enact using 'life' are worthy enough to value life [Tao Te Ching Chapter 75].

\section{Conclusion}

Taoism as both religion and socio-political philosophy of the Chinese people has provided the modern world with alternative model of peace building and conflict management. This method is anchored on the basic canon of Yin-yang, which encourages pluralism of ideas, opinions, thoughts, culture and approaches. It underscores that truth is not in the extreme and reality/nature [the Tao] does not present itself in mono vision but in diversity of models, often in non -complementary nature. However, in such opposing visions, nature [The Tao] maintains its balance/ harmony. The next important concept of Taoism, through which the society attains peace and stability is Wu-wei [non Interference]. Here the imagery of Wu-wei is water or rather a flowing river. It maintains that water does not struggle with anything. It demonstrates powerlessness and subtlety and does not meddle and yet conquers 
all oppositions/obstacles and by the principle of non-doing, it achieves everything. This ideology is represented by the epithet 'action in inaction' It notes that the two models are the natural ways of the Tao [nature or reality] and the experience of the horrid conflicts that have dotted our socio-political history is because we have neglected this pristine approach to human relationship and social organization. Consequently, this paper, having taking time to study these principles of Peace building and conflict management in Taoist tradition, opines that if the current world system organized round the globalization of culture, knowledge, life, business, politics etc, shall adopt the Taoist model, our world of $21^{\text {st }}$ century shall soon be a conflict free world.

\section{References}

Brooker, Moore and Kenneth Brunder [1998]. Lao Tzu on Political Theory. Maryland: IVP.

Burroughs William [2008]. Taoism and the Concept of Inaction, accessed on 16/01/2015 from www.understandinglaoismtoday.org/edu.

Chang Chung Yuam [1978] [Trans] Tao Te Ching. New York: Harper and Row Publishers.

Edet Messembe [2006] Outlines of Oriental Philosophy: Calabar: Index Educational Foundation Publishers.

Hansen Chad [2015]. Chinese Philosophy. Accessed on $16^{\text {th }}$ January, 2015 from aku.hk/philodep.org.

Hays, Jeffery [2013] "Facts and Details: Taoist Belief, Practice and Deities" Encyclopaedia publication, http://asiaobscura.com.

Henderson John [1984]. The Development and Decline of Chinese Cosmology. New York: Columbia University Press.

Kurdash Teel [1993] Taoism-The Wu-wei Principle Part 4 Jade dragon Online. Accessed on 16/01/2015 from . http://wwwtaoistprinciple-wu-vvei.org/edu.

Legge James [ 1994]. The Chinese Classics: The Ch'ien Ts;ew, with Tso Chuen. Taipei: SMC Publishing.

Marina Martins [2001] Capitalism and The Tao accessed from www index-china.com2001. on $16^{\text {th }}$ January, 2015.

Okoro Kingsley N and Osunwokeh Clement [2014] "Common Humanity not Common Community: The Solution to Global Crisis" African Journal of Political Science and International relation Vol 7 [1] 12-23. http://www.acadeicjoumals.org/AJPSIR, doi 10.5879/
AJPSIR2.060.

Okoro Kingsley N [2012] "Religion in an Oppressive Society: The Ante Bellum Example "Open Journal of Philosophy 2012. Vol 2, No 4 [251-259] http:/ www.sciRP.org/journsal/ojpp. Doi org/10.4236/ojpp 2012.24037.

Okoro Kingsley N [2013] "African Concept of Inochi': A New Paradigm for Peace Education in the Contemporary Society" Modern Social Sciences Journal 2[2013] No2 87-112 http://scik.org.

Okoro Kingsley N [2014] "An inquest into Common Humanity through Myths and Mythologies: Joseph Campbell's Paradigm" Scholars Journal of Arts, Humanities and Social Sciences 2014.2[1] 79-93. http:// saspiournal.com/siahss.

Okoro Kingsley N and Osunwokeh Clement I [2014] 'Religion and Human Rights Violation in History: The Women and Witch Hunts in Medieval Europe. 'Journal of Scientific Research and Reports 3 [24] 3045-3069 www.sciencedomian,org. doi 10.9734/ jsrr/2014/10352.

Omeregbe Joseph [1991] Philosophical Look at Religion. Lagos: Joja Educational Research and Publications.

Pregadio Fabrizo [2015] New Dictionary of History of Ideas: Modern Encyclopaedia accessed on $16^{\text {th }}$ January, 2015 on http:/www.encyclopaedia.com.

Rennet isabelle [1997] Taoism: Growth of a Religion. Translated by Phyllis Books: Stanford Cliff: Stanford University Press.

Sabine George and Thomas Thorson [1993] A History of Political Theory [ $4^{\text {th }}$ edition] New Delhi: Oxford IBH Publishing

Shade W.G and Roy HC [1969] Seven on Black: Reflections on Negro Experiences in America. Philsdelphia: JB Lippincott Company.

Taoism: As Live by Pooh and Piglet [2015].http:// www.taoisminthemodernworldpolitics.org.accessed on $16^{\text {th }}$ January, 2015.

TCM World Foundation [2015]. Yin and Yang Theory Encompassing Everything in the Universe. Accessed on the $16^{\text {th }}$ of January, 2015 from http:// www.tcmworld.org/what-is-tcm/yin-yangtheory/sllh. hv.wgScpk.dpuf.

The Tao Bums: Discussions on the Way [2015] accessed from www.taoismandiTiodemphilosphy.org/ edu. On $16^{\text {th }}$ January, 2015.

Toropov Brandon [2011]. The Complete Idiot's Guide to Taoist accessed on $16^{\text {th }}$ January, 2015 from taoismphilosopydup.org/edu. 
Uchegbue Christian O [1997]" Karl Marx's Theory of Religion" In the Great Philosophers Vol 11. Edited by Ozumba Godfrey. Aba: Vitalis books.

Ulrich Philips [199] A Documentary History of America Industrial Society. Cleveland: Author H Clarks.

Wang R. Robin [2015] Internet encyclopaedia of Philosophy, accessed on the $16^{\text {th }}$ of January, 2015 from http://www.encyclopeadiaofphilosophy.org/edu.

Watts Allan [2008] Taoism and Wu-wei accessed 16/01/2015 from www.taoisinprinciplesand practice. org/edu.

Woff Richard [2007]. The Popular Encyclopaedia of World Religions. Oregon: Harvest House Publishers. 